University of Wollongong

Research Online

Faculty of Commerce - Papers (Archive)

Faculty of Business and Law

January 2010

\title{
The influence of board size on intellectual capital disclosure by Kenyan
}

listed firms

Indra Abeysekera

University of Wollongong, indraa@uow.edu.au

Follow this and additional works at: https://ro.uow.edu.au/commpapers

Part of the Business Commons, and the Social and Behavioral Sciences Commons

\section{Recommended Citation}

Abeysekera, Indra: The influence of board size on intellectual capital disclosure by Kenyan listed firms 2010, 504-518.

https://ro.uow.edu.au/commpapers/761

Research Online is the open access institutional repository for the University of Wollongong. For further information contact the UOW Library: research-pubs@uow.edu.au 


\title{
The influence of board size on intellectual capital disclosure by Kenyan listed firms
}

\author{
Abstract \\ Purpose - The purpose of this paper is to examine the effect of board size on firms disclosing more, \\ rather than less, strategic and tactical intellectual capital resources using the top 26 of the 52 firms \\ ranked by the Nairobi Stock Exchange for market capitalization in 2002 and in 2003. This study identifies \\ intellectual capital disclosure by three separate categories: internal capital, external capital, and human \\ capital. Hence, this study examines the influence of board size on six disclosure outcomes. Design/ \\ methodology/approach - The study develops hypotheses using the resource dependency theory. Using \\ content analysis for data generation, this study classifies firms that disclose more versus those that \\ disclose less, using the mean for all firms for each disclosure outcome. Findings - Using logistic \\ regression, the study examines the influence of board size on each disclosure outcome and finds that \\ firms disclosing more tactical internal capital and more strategic human capital have larger boards. \\ Practical implications - The findings provide insights into how a larger board size can help boards to \\ overcome skill deficiencies in making more discretionary disclosure related to future earnings. Originality/ \\ value - This study analyses the influence of the board size on six aspects of intellectual capital \\ disclosure.

\section{Keywords} \\ capital, board, size, disclosure, firms, listed, kenyan, influence, intellectual

\section{Disciplines} \\ Business | Social and Behavioral Sciences

\section{Publication Details} \\ Abeysekera, I. (2010). The influence of board size on intellectual capital disclosure by Kenyan listed firms. \\ Journal of Intellectual Capital, 11 (4), 504-518.
}




\section{The influence of board size on intellectual capital disclosure by Kenyan listed firms}

\section{Author}

Indra Abeysekera, University of Wollongong

\section{Document Type}

Journal Article

\section{Publication Details}

This article was originally published as Abeysekera, Indra, The influence of board size on intellectual capital disclosure by Kenyan listed firms, Journal of Intellectual Capital, 11(4), 2010, 504-518 


\title{
The influence of board size on intellectual capital disclosure by Kenyan listed firms.
}

\begin{abstract}
Purpose - Using the top 26 of the 52 firms ranked by the Nairobi Stock Exchange for market capitalization in 2002 and in 2003, this study examines the effect of board size on firms disclosing more rather than less strategic and tactical intellectual capital resources. This study identifies intellectual capital disclosure by three separate categories: internal capital, external capital, and human capital. Hence, this study examines the influence of board size on six disclosure outcomes.

Design/Methodology/Approach - The study develops hypotheses using the resource dependency theory. Using content analysis for data generation, this study classifies firms that disclose more versus those that disclose less, using the mean for all firms for each disclosure outcome.

Findings - Using logistic regression, the study examines the influence of board size on each disclosure outcome and finds that firms disclosing more tactical internal capital and more strategic human capital have larger boards.

Practical implications - The findings provide insights into how a larger board size can help boards to overcome skill deficiencies in making more discretionary disclosure related to future earnings.

Originality/Value - This study analyses the influence of the board size on six aspects of intellectual capital disclosure.
\end{abstract}

Keywords: board size, intellectual capital, strategic, tactical 


\section{Introduction}

The low business skills of the board members of Kenyan firms are a concern for investors assessing the boards' ability to provide future-earnings information (Gatamah, 1999). This study examines the governance attributes of the top 26 of the 52 firms listed with the Nairobi Stock Exchange, over a two-year period (2002 to 2003), to determine whether a larger board enables Kenyan listed firms to overcome the business-skill crisis through collective decision-making. The business acumen of the directors becomes crucial in determining discretionary disclosure of economic resources not mandated in financial statements. The inclusion in annual reports of these unaccounted economic resources, which impact future earnings, can enhance stock price and help firms reduce cost of funds. This study uses intellectual capital resources as a proxy for firms' unaccounted economic resources. Although definitions of intellectual capital are diverse (Edvinsson and Sullivan, 1996; Brooking, 1997), a widely agreed interpretation is that it represents the "unaccounted economic capital" of future earnings not captured in financial statements (Simister, Roest, and Sheldon, 1998, p. 2). Such disclosure is particularly important in the context of Kenya, with Kenyan listed firms seeking to expand and take advantage of the economic integration of the East African community (Mwebesa, 2006).

This study expects that firms with larger boards can mitigate individual directors' deficiencies in business skills through collective decision-making. Since intellectual capital resources can contribute to future earnings over different time horizons, this study employs a panel of ten experts knowledgeable about intellectual capital research and/or 
practice to identify and classify intellectual capital resource items as strategic or tactical resources. This study considers resource items thought to contribute to future earnings for more than one future year as strategic, and items contributing for less than a year as tactical, based on the majority opinion of the expert panel. This study identifies intellectual capital resource items by three separate categories (internal capital, external capital, and human capital) to gain a detailed insight into the influence board size has on the strategic and tactical resource disclosure of internal capital, external capital, and human capital.

This study notes that there are other ways of categorizing intellectual capital. Edvinsson and Malone (1996) categorize it as structural capital and human capital, where structural capital encompasses internal capital and external capital. Sveiby (1997) categorizes it as internal structure, external structure, and employee competence. These categories were later reclassified by numerous authors as internal capital, external capital, and human capital on the basis that intellectual capital comprises capital categories rather than structures (Abeysekera, 2006; 2008; Abeysekera \& Guthrie, 2005; Brennan, 2007). A detailed categorization of intellectual capital (as three categories rather than two categories) enables this study to provide a more detailed view about the influence of board size on tactical and strategic disclosure by categories of intellectual capital.

The next section outlines the theoretical framework, reviews the literature in relation to variables examined in this study, develops hypotheses, and introduces the use of variables 
in the study. Section 3 outlines the research method used. Section 4 presents the findings, discussion, and concluding remarks.

\section{Literature, framework, and hypotheses}

\section{Relevant literature}

Corporate governance establishes the framework for efficiency and probity, and for firms' transparency and accountability. Corporate governance deals with the ways of assuring suppliers of firms' financing of a return on their investment (Shleifer and Vishny, 1997). Many developing countries, including Kenya, formalized corporate governance best practice codes in 2001 (one year prior to this study), adopted from best practice codes of developed countries, while giving little thought to underlying conditions in the marketplace in which the codes are enforced and practiced. Although near replication of governance practices of firms in developed countries is not necessarily appropriate for firms in a developing country, better governance practices expect to make firms more accountable and transparent through stakeholders' relevant disclosure.

Investors are an important group of stakeholders in business ventures, and they seek information that is relevant for making informed decisions about firms' investments. Discretionary disclosure about aspects such as intellectual capital with an economic focus is directly relevant to investors for such decision-making (Lev and Zarowin, 1999; Eccles, Herz, Keegan, and Phillips, 2001; Lev, 2001). Such disclosure reduces risk perception among investors by facilitating a more accurate estimation of future earnings 
(Keenan and Aggestam, 2001; Van der Meer-Kooistra and Zijlstra, 2001; Li, Pike, and Haniffa, 2008).

Barako, Hancock, and Izan (2006) examined the corporate disclosure of Kenyan listed firms and the effect of corporate governance and ownership characteristics. The present study differs from theirs along several dimensions. First, instead of examining all corporate disclosure, this study specifically focuses on intellectual capital disclosure that has an economic focus. Second, the central focus of this study is the influence of the board size rather than all corporate governance attributes. This study uses other relevant corporate governance attributes identified in the literature as control variables. Barako et al. examined the proportion of independent directors and the presence of an audit committee, as they used the theoretical underpinning of the agency perspective. By contrast, the current study uses the number of independent directors on the board, and the number of independent directors on committees, because of the resource dependency underpinning of the study, an aspect which is discussed later in this paper. Third, unlike Barako et al., the present study examines the disclosure in strategic and tactical categories of intellectual capital.

Two other studies of relevance to intellectual capital disclosure are Cerbioni and Parbonetti (2007) and Li et al. (2008). Cerbioni and Parbonetti examined intellectual capital disclosure of European biotechnology firms. They examined both the quantity and quality (measured by economic sign, outlook orientation, and content of information) of intellectual capital, with board size, proportion of independent directors, and leadership 
as governance attributes of these firms. Li et al. examined 100 sample UK listed firms. They categorized intellectual capital into human, structural, and relational capital, measured disclosure of each category by a disclosure index developed especially their study, and investigated the influence of corporate governance attributes on disclosure category. Both studies however did not investigate the impact of governance attributes in relation to strategic and tactical intellectual capital disclosure. Additionally, both studies were located in developed countries, and used the agency theoretical perspective in developing their hypotheses and interpreting findings.

\section{Resource dependency theory}

Much of the discretionary disclosure literature related to governance has theorized using stewardship, and the agency perspective. According to stewardship theory, managers are honest rather than opportunistic in taking care of the wealth of the firm (Muth and Donaldson, 1998). This theory supports empowering corporate structures and governance mechanisms to allow managers and directors to make decisions efficiently and effectively. For example, the duality of the CEO also being the chairperson is beneficial to the firm under the stewardship perspective. In addition, executive directors are better than independent directors at formulating and managing corporate affairs due to their superior inside knowledge of the firm (Donaldson and Davis, 1991, 1994). Another dominant theory about corporate governance is the agency perspective, which considers that self-interest of managers and directors within the firm can compromise the best interest of investors (Fama, 1980; Fama and Jensen, 1983). According to this theory, corporate boards that include independent directors take on the monitoring role of 
mitigating the self-interest of executive directors and managers that compromises investors' interests (Demirag, Sudarsanam, and Wright, 2000). Larger boards are difficult to control by the chairperson, and smaller boards are hence preferred for good-quality relevant disclosure (Hermalin and Weisbach, 2003; Kaymak and Bektas, 2008).

Rather than dichotomizing directors as executive and non-executive, the resource dependence theory views the entire board as a mechanism that manages to reduce external uncertainties (Pfeffer and Salancik, 1978). Directors bring diverse resources such as information, skills, and legitimacy (Hillman, Canella, and Paetzold, 2000). Although a widely held assumption is that the board of directors is interested in the long-term value of the firm (Laux and Laux, 2009), there is no consensus in the literature as to the recommended size of the board. The Olivencia report in Spain suggested that the optimal number of directors is between 5 and 15 (Garcia Lara, Garcia Osma, and Penalva, 2007). From a resource dependency perspective, larger boards should be more effective than smaller boards, as larger boards can make better collective decisions.

\section{Hypothesis development with board size as an independent variable}

Intellectual capital has become a key set of resources for gaining advantage in a business environment that transcends fixed geographic boundaries (Lev, 2004). The resource dependency theory adopted in this study argues that larger boards allow firms to bring diverse and vital resources onto the board that can make the board's decision-making effective and efficient directly or indirectly, meeting challenges in the globalized business environment (Pfeffer, 1972, 1973; Pfeffer and Salancik, 1978; Kosnik, 1990; Parum, 
2005). The size of the board can add to the diversity of perspectives, providing greater choices among solutions and more decision criteria, to achieve the board's goals and objectives on behalf of investors (Schweiger, Sandberg, and Ragan, 1986; Eisenhardt and Bourgeois, 1988). Examining the banking industry from 1995 to 2002, Belkhir (2009) found that larger boards contribute to banks' better performance, where performance is measured by Tobin's $\mathrm{Q}$.

This theoretical perspective is relevant to the present study of the top listed Kenyan firms, as demonstrated by the investigation of corporate governance practices undertaken in Kenya, where a critical issue is the skill level of directors (Gatamah, 1999), since larger boards can supplement skill deficits of directors at an individual level. Furthermore, the theoretical underpinning motivates this study to examine board size as a measure of number of directors. This study also measures other factors controlled as a number rather than as a proportion or as being either present or absent. These include the number of independent directors on the board, and the number of independent directors in committees and the number of committee meetings (Spira, 2002; Higgs, 2003; Tuley, 2003). These factors were also examined in previous studies that use the agency theoretical setting as proportions rather than as numbers.

\section{Human capital:}

The human capital in a firm includes tactical resources from which the firm derives benefit in the short term. For instance, a change in relations between employee unions and the management can have a tactical effect on future earnings. By contrast, the tacit 
knowledge of staff is a strategic source for future earnings of firms (Barney, 1991; Coff, 1997; Roos and Roos, 1997, p. 413). The firm, through direct acquisition and investment in developing resources such as tacit knowledge of staff, can nurture the strategic human capital resources. However, investors become aware of the future earnings capability engendered by these resources only with their disclosure. This study assumes that larger boards ensure communication to investors of the strategic resources of human capital to demonstrate long-term future earnings of the firm, through greater voluntary disclosure. Strategic human capital resources are invaluable and are a primary set of resources whereby many firms sustain their competitive advantage (Quinn, Anderson, and Finkelstein, 1996). The tactical human capital is captured to some extent in financial statements as expenses (rather than as assets), giving investors some indication of its value relevance. Therefore, this study hypothesizes that firms with larger boards disclose more strategic human capital resources but not more tactical human capital resources.

\section{H1: Firms that disclose more strategic human capital have larger boards.}

H2: Firms that disclose more tactical human capital do not have larger boards.

\section{Internal capital:}

Investment in the strategic resources of human capital is challenging to management because it has little control over such resources as staff; the firm does not own these resources in the form of knowledge (Coff, 1997). The lack of full ownership of strategic human capital resources, and the high uncertainty of predicting staff behavior and tenure, requires firms to "capture" the tacit knowledge aspects of strategic human capital 
resources and to make them explicit. Firms gain control over such strategic resources through activities such as sharing employee presentations at work, teamwork, and formalizing technological and management processes. Tactical internal capital resources, such as networking systems and information systems, enable firms to disseminate the once-tacit knowledge, now captured by the firm as explicit knowledge (Quinn et al., 1996; Grant, 1997). The tactical resources of internal capital, such as processes and systems, enable firms to obtain the benefits of the strategic resource of human capital and own them. This study hypothesizes that firms with larger boards disclose more tactical internal capital to enhance future earnings information. The strategic internal capital resources such as corporate philosophy and corporate culture are of significance to firms for internal decision-making as they represent human capital transformed into a static organizational form. The strategic internal capital resource information is useful to the internal management rather than to investors for on resource allocation decisions.

\section{H3: Firms that disclose more strategic internal capital do not have larger boards.}

H4: Firms that disclose more tactical internal capital have larger boards.

\section{External capital:}

External capital is the most disclosed of the three intellectual capital categories (Brennan, 2001; Bozzolan, Favotto, and Ricceri, 2003; Abeysekera, 2007). Much information about firms' external capital resources is widely known to investors, as firms create these resources by establishing external relations with stakeholders. Although disclosure reinforces the presence of such resources, investors have already recognized the future 
earnings capability as this information is widely known, and discretionary disclosure has no additional effect on future earnings. Therefore, this study expects to find no association between firms that disclose more external capital information and better governance practices. This study hypothesizes that firms that disclose more strategic external capital and tactical external capital do not associate with larger boards.

H5: Firms that disclose more strategic external capital information do not have larger boards.

H6: Firms that disclose more tactical external capital information do not have larger boards.

\section{Control variables:}

This study uses several established variables in governance studies with agency theory that might have an influence on discretionary disclosure. However, as this study is using the resource dependency underpinning, it assumes that these variables have no influence on firms making strategic and tactical disclosure relating to internal, external, or human capital. The variables include number of independent directors in audit committee, number of independent directors in other board-appointed committees, firm size, and industry sector. The study also identifies the year of disclosure and the company identity as control variables to identify whether the year of investigation and specific companies influence firms making more disclosure.

\section{Defining variables}


Because the dependent variables are binary (more disclosure versus less disclosure, as explained later), this study uses logistic regression to test its hypotheses. Listed below are the six dependent variables, the independent variable board size, and several control variables, and their predicted signs are summarized in Table 1.

Dependent variables:

(1) $\operatorname{SIntCD}($ Strategic internal capital disclosure $)=1=$ above sample mean, $0=$ equal to, or below sample mean

(2) $\operatorname{SExtCD}($ Strategic external capital disclosure $)=1=$ above sample mean, $0=$ equal to, or below sample mean

(3) SHumCD (Strategic human capital disclosure) =1=above sample mean, $0=$ equal to, or below sample mean

(4) $\operatorname{TIntCD}($ Tactical internal capital disclosure $)=1=$ above sample mean, $0=$ equal to, or below sample mean

(5) TExtCD (Tactical external capital disclosure $)=1=$ above sample mean, $0=$ equal to, or below sample mean

(6) THumCD (Tactical human capital disclosure $)=1=$ above sample mean, $0=$ equal to, or below sample mean

Independent variable:

(7) BOARDSIZE $($ Board size $)=$ Number of directors on the board of directors between 5 and $14=1$, otherwise 0

\section{Control variables:}


(8) NID (Number of independent directors on the board)

(9) NIDAC (Number of independent directors in the audit committee)

(10) NIDATC (Number of independent directors in committees other than the audit committee)

(11) SIZE (Firm size measured as sales revenue for the year of investigation)

(12) IND (Industry = ratio of market price to net book value at the year of investigation)

(13) YEAR $($ Year $)=2002=1$, and 2003=2

(14) ID (Company identification number)

Table 1

Summary of variables and their predicted signs on disclosures

\begin{tabular}{|l|l|l|l|l|l|l|}
\hline & SIntCD & TIntCD & SExtCD & TExtCD & SHumCD & THumCD \\
\hline Board size & Nil $(\mathrm{H} 3)$ & $+(\mathrm{H} 4)$ & Nil $(\mathrm{H} 5)$ & Nil (H6) & $+(\mathrm{H} 1)$ & Nil (H2) \\
\hline $\begin{array}{l}\text { Control } \\
\text { variables }\end{array}$ & Nil & Nil & Nil & Nil & Nil & Nil \\
\hline
\end{tabular}

For each of the dependent variables, the logit regression equation was as follows.

Dependent variable (i.e., (1) to (6)) $=\mathrm{a}+\mathrm{b}^{*}$ BOARDSIZE $+\mathrm{c}^{*} \mathrm{NID}+\mathrm{d}^{*}$ NIDAC $+e^{*}$ NIDATC + f*SIZE $+f * I N D+g *$ TIME $+h *$ ID $+e$

\section{Research methods}

\section{Data source}


Studies of firms in many countries have attempted to explore intellectual capital disclosure practices through an analysis of company annual reports (Brennan, 2000; Bozzolan et al., 2003). Annual reports are the principal tool of corporate communication about the tactical and strategic activities of the firm, additional to the mandatory financial statement disclosure (Holland and Boon Foo, 2003). An annual report signals financial and non-financial information relevant to decision-making about the firm, both to investors and to analysts who act as intermediaries providing information to the investing market. Several studies have identified an increasing trend in discretionary disclosure about firms' intellectual capital (Williams, 2001; Beattie, McInnes, and Fearnley, 2002; Vandemaele, Vergauwen, and Smits, 2005).

Discretionary intellectual capital disclosure is an invaluable tool for instilling confidence in the marketplace about firms, enhancing the capacity of firms to lower their cost of capital (Lev, 1992; Palepu and Healy, 1993). The Nairobi Stock Exchange has become an important source for accessing cheaper finance for the corporate sector, mobilized through local and foreign investors. The previously tarnished image of poor-quality disclosure has urged listed Kenyan firms to become more informative about future earnings (World Bank, 2001). Additionally, the issuance in 2001 of mandatory corporate governance guidelines for listed Kenyan firms might have positively contributed to uplifting the discretionary disclosure quality. For these reasons, this study assumes a higher discretionary disclosure quality for all firms, since the sample firms in this study constitute the top 26 firms by market capitalization (nearly 50\% of firms) in 2002 and in 2003, among the 52 listed firms. 


\section{Data collection}

Content analysis is an empirically valid tool for analysis of corporate disclosure (Guthrie and Parker, 1990; Hackston and Milne, 1996). This study analyses annual reports using content analysis technique, a widely used tool in intellectual capital disclosure studies (Brennan, 2001; Haniffa and Cooke, 2005; Cerbioni and Parbonetti, 2007). The content analysis captures intellectual capital resource items disclosed in annual reports (Haniffa and Cooke, 2005) using an established coding framework. Previous studies have applied the coding framework used in this study to the top listed firms in a developing country setting, with 45 intellectual capital resource items (Abeysekera, 2007), and is applied in this study for Kenyan listed firms in a developing country setting. The coding framework identifies intellectual capital resource items as being in the internal capital category (10 items), the external capital resource category (10 items), or the human capital resource category (25 items). Additionally, this study pre-defined each resource item in the coding framework as to whether it has strategic or tactical value relevance (Abeysekera, 2007) and two experienced people coded each annual report independently. Each time a resource item was identified as present in the annual report it was counted as 1 . After two

people experienced in coding content data had coded annual reports independently using the pre-defined terms, the coding between the two coders was compared using Scott's $\pi$ (1955) and the score obtained was greater than 0.9, which confirmed meeting the satisfactory coding reliability level.

\section{Measuring dependent variables - disclosure indices}


A disclosure index or content analysis does not reduce the effectiveness of regression results (Hackston and Milne, 1996; Williams, 1998); rather, it is the rigor of construction of the disclosure index that determines its reliability (Barako et al., 2006). As a precursor to ensure rigor of construction, this study ensures meeting satisfactory reliability using Scott's $\pi$ for disclosures recorded by the two coders. Additionally, the study uses intellectual capital resource items applicable to a developing-country setting (Abeysekera and Guthrie, 2005; Abeysekera, 2007).

Instead of assigning weights to different types of intellectual capital resource items disclosed (i.e., narrative, visual, or numerical), a procedure which can introduce errors due to bias, this study treats each type of disclosure with equal importance. This study constructs disclosure indices for six outcome variables. For this purpose, the study identified intellectual capital resources that are strategic or tactical. Five items (patents, copyrights, trademarks, corporate philosophy, and corporate culture) are identified as strategic internal capital items (falling within the internal capital category). Five items (brands, corporate name, favorable contracts, distribution channels, and market share) are identified as strategic external capital. Twelve items (professional experience, educational level of staff, seniority of experts, age of staff, professional qualifications, vocational qualifications, career development, training programs, safety at work, gender equality, race and religion of staff, and equality of disabled staff) are identified as strategic human capital. 
Disclosure indices are built for strategic internal capital (5 items), strategic external capital (5 items), and strategic human capital (12 items). Additional disclosure indices are for tactical internal capital (5 items), tactical external capital (5 items), and tactical human capital (13 items). This study constructs six disclosure indices for strategic and tactical disclosure: (1) strategic internal capital disclosure index; (2) tactical internal capital disclosure index; (3) strategic external capital disclosure index; (4) tactical external capital disclosure index; (5) strategic human capital disclosure index; and (6) tactical human capital disclosure index. These indices serve as preceding information to construct dependant variables. To build the binary code for logistic regression for each dependent variable, the mean for each index of disclosure is then calculated, and firms that are above the mean are assigned "1" and those below or equal to the mean are assigned "0." There are 6 disclosure indices, for each of which a binary dependant variable is constructed, and the study examines 6 dependant variables.

\section{Results and discussion}

Table 2 outlines summary statistics. Many firms have larger boards than the sample mean for board size, the maximum board size is 13 , and the maximum board size is within the range of optimum board size suggested by the Olivencia report in Spain (Garcia Lara et al., 2007). Firms on average have 3 independent directors on the audit committee and 3 independent directors in committees other than the audit committee. On average, firms maintain a net book value slightly higher than the market value. Firms have low growth rate as seen by industry sector measure of price-to-book value, and the negative price-tobook value is due to firms having a net liability position or liquidity of the market. 
Table 2

Summary statistics $(\mathrm{N}=52)$

\begin{tabular}{|l|r|r|r|r|}
\hline & \multicolumn{1}{|l|}{ Mean } & Std. Dev. & Minimum & Maximum \\
\hline SIntCD & 0.808 & 0.398 & 0 & 1 \\
\hline TIntCD & 0.519 & 0.505 & 0 & 1 \\
\hline SExtCD & 0.500 & 0.505 & 0 & 1 \\
\hline TExtCD & 0.654 & 0.480 & 0 & 1 \\
\hline SHumCD & 0.442 & 0.502 & 0 & 1 \\
\hline THumCD & 0.635 & 0.486 & 0 & 1 \\
\hline BOARDSIZE & 8.058 & 2.321 & 3 & 13 \\
\hline NID & 3.346 & 2.535 & 0 & 10 \\
\hline NIDC & 2.865 & 2.842 & 0 & 10 \\
\hline SIZE (in Mn KES.) & 5.191 & 7.462 & 0.048 & 27.7 \\
\hline IND & 0.960 & 1.212 & -1.67 & 5.93 \\
\hline
\end{tabular}

The preliminary data analysis revealed that the number of independent directors on audit committee and audit-type committees is highly correlated as follows: NIDAC = 0.9127*NIDATC. A composite variable was built to replace the two variables (i.e., $\left.0.5^{*}(\mathrm{NIDAC}+0.9127 * \mathrm{NIDATC})\right)$, and it was labeled number of directors in committees (NIDC). The VIF for variables varied between 1.11 and 2.95 in all logistic regression outputs. This study revised the previously stated logistic regression equation as follows:

Dependent variable (i.e., (1) to (12)) $=\mathrm{a}+\mathrm{b}^{*}$ BOARDSIZE $+\mathrm{c}^{*} \mathrm{NID}+\mathrm{i}^{*}$ NIDC $+e^{*}$ SIZE $+\mathrm{f}^{*}$ IND $+\mathrm{g} * \mathrm{TIME}+\mathrm{h} * \mathrm{ID}+\mathrm{e}$

The results from Table 3 indicate that firms that disclose more human capital resources have larger boards, but those firms that disclose more tactical human capital resources do not have larger boards, which is consistent with $\mathrm{H} 1$ and H2. Firms with larger boards disclose more tactical internal capital but firms that disclose more strategic internal capital do not have larger boards, which is consistent with $\mathrm{H} 3$ and H4. The board size has 
no influence on tactical or strategic external capital disclosure, which is consistent with H5 and H6. 
Table 3

Results from strategic and tactical disclosure

\begin{tabular}{|c|c|c|c|c|c|c|c|c|c|c|c|c|}
\hline $\begin{array}{l}\text { Dependent } \\
\text { variable }\end{array}$ & $\begin{array}{l}\text { SIntCD } \\
\text { Index }\end{array}$ & & $\begin{array}{l}\text { TIntCD } \\
\text { Index }\end{array}$ & & $\begin{array}{l}\text { SExtCD } \\
\text { Index }\end{array}$ & & $\begin{array}{l}\text { TExtCD } \\
\text { Index }\end{array}$ & & $\begin{array}{l}\text { SHumCD } \\
\text { Index }\end{array}$ & & $\begin{array}{l}\text { THumCD } \\
\text { Index }\end{array}$ & \\
\hline $\begin{array}{l}\text { Independent } \\
\text { and control } \\
\text { variables }\end{array}$ & $\begin{array}{l}\text { Odds } \\
\text { ratio }\end{array}$ & $\operatorname{Pr}$ & $\begin{array}{l}\text { Odds } \\
\text { ratio }\end{array}$ & pr & $\begin{array}{l}\text { Odds } \\
\text { ratio }\end{array}$ & $\operatorname{Pr}$ & $\begin{array}{l}\text { Odds } \\
\text { ratio }\end{array}$ & $\operatorname{Pr}$ & Odds ratio & $\mathrm{pr}$ & Odds ratio & $\operatorname{Pr}$ \\
\hline BOARDSIZE & 1.067 & 0.978 & 8.721 & 0.027 & 3.131 & 0.215 & 1.550 & 0.668 & 5.573 & 0.093 & 2.132 & 0.487 \\
\hline NID & 1.244 & 0.686 & 1.015 & 0.955 & 0.939 & 0.799 & 1.104 & 0.724 & 0.688 & 0.172 & 0.780 & 0.400 \\
\hline NIDC & 0.801 & 0.505 & 0.931 & 0.733 & 1.324 & 0.251 & 1.258 & 0.472 & 1.390 & 0.216 & 1.965 & 0.077 \\
\hline SIZE & 1.000 & 0.034 & 1.000 & 0.168 & 1.000 & 0.28 & 1.000 & 0.069 & 1.000 & 0.095 & 1.000 & 0.049 \\
\hline IND & 0.956 & 0.92 & 0.775 & 0.451 & 1.068 & 0.808 & 2.502 & 0.171 & 0.930 & 0.789 & 4.141 & 0.110 \\
\hline TIME & 81.718 & 0.192 & 1.048 & 0.943 & 0.910 & 0.882 & 0.307 & 0.136 & 0.209 & 0.023 & 0.791 & 0.763 \\
\hline ID & 1.020 & 0.805 & 1.002 & 0.959 & 0.999 & 0.974 & 1.115 & 0.085 & 0.997 & 0.955 & 1.125 & 0.068 \\
\hline No of firms & 52 & & 52 & & 52 & & 52 & & 52 & & 52 & \\
\hline$C h i^{2}$ & 30.43 & & 12.95 & & 9.29 & & 19.06 & & 15.81 & & 20.06 & \\
\hline$P r$ & 0.000 & & 0.073 & & 0.232 & & 0.008 & & 0.027 & & 0.005 & \\
\hline
\end{tabular}


As noted earlier in developing hypotheses, larger boards attempt to demonstrate that they maintain future earnings from intellectual capital resources by codifying strategic human capital that is tacit in nature with tactical internal capital, to disclose to investors that tacit knowledge is made explicit in firms to sustain future earnings from intellectual capital resources.

The number of independent directors in committees is significant for firms that disclose more tactical human capital resources. To find out which committee types of independent directors of committees associate with tactical human capital resources disclosure, the NIDC variable was replaced with NIDAC and thereafter with NIDATC. The results showed that NIDAC is not significant but NIDATC is significant, with odds ratio of 1.4 ( $\mathrm{pr}=0.076$, model chi-square 19.05, and $\mathrm{pr}=0.008$ ). This is a plausible finding, as the mandate of independent directors in non-audit committees (usually remuneration) is to oversee transparency relating to aspects of remuneration, recruitment, and operational management of human resources. The findings partially support the resource dependency perspective only.

This study demonstrates the mechanisms firms can employ to overcome short-term limitations, such as mitigating low skill level of directors by having larger boards. However, this study has several limitations. It classified resource items as tactical and strategic based on the majority opinion of the expert panel. A more rigorous benchmark might have proved more useful to present findings that are more robust. In identifying independent directors, this study relied on prima facie evidence in annual reports, but 
executive directors might influence some of the independent directors. Audit and other board-appointed committees might have a useful role to play in aspects of intellectual capital disclosure not captured in this study, as this study did not examine the informal processes in which these committees could have an impact on organizational life (Spira, 2002; Tuley, 2003). The small sample size is a limitation inherent to the world's small stock exchanges such as Nairobi Stock Exchange. Despite these limitations, this study contributes to the much-needed findings on the aspects of intellectual capital disclosure and board size in the context of Africa, and in particular for the East African financial hub of Kenya.

Board size can be a 'resource' to companies that inform investors about future earnings through intellectual capital. Such disclosures can help firms to improve their share price by informing investors about resources not disclosed in financial statements. A future study can examine attributes of board members and the influence of each attribute on strategic and tactical intellectual capital disclosure. For instance, the reputational aspects of the board members, educational qualifications, multiple representations on company boards by board members, and board tenure, may influence strategic and tactical intellectual capital disclosures. Another study can examine whether such attributes of board members involved in board-appointed committees have an influence on strategic and tactical intellectual capital disclosures. As noted in the introduction, larger boards can mitigate individual directors' deficiencies in business skills through collective decision making. However, this may not be contextual to other samples with different board 
compositions, and therefore this study can become a basis for comparison for such structural differences. 
References

Abeysekera, I. (2006), "The project of intellectual capital. Researching the research," Journal of Intellectual Capital, Vol. 7, No.1, pp. 61-77.

Abeysekera, I. (2008), “Intellectual capital disclosure trends: Singapore and Sri Lanka," Journal of Intellectual Capital, Vol. 9, No. 4, pp. 723-737.

Abeysekera, I. (2007). Intellectual capital accounting: Practices in a developing country. New York: Routledge.

Abeysekera, I., and Guthrie, J. (2005), 'An empirical investigation of annual reporting trends of intellectual capital in Sri Lanka," Critical Perspectives on Accounting, Vol. 16, No.3, pp. 151-63.

Barako, D. G., Hancock, P., and Izan, H. Y. (2006), "Factors influencing voluntary disclosure by Kenyan companies," Corporate Governance, Vol. 14, No. 2, pp. 107-125.

Barney, J. (1991), “Firm resources and sustained competitive advantage,” Journal of Management, Vol. 17, pp. 99-120.

Beattie, V., McInnes, B., and Fearnley, S. (2002), Through the eyes of management: A study of narrative disclosures. An interim report. London: Centre for Business Performance, Institute of Chartered Accountants in England and Wales. 
Belkhir, M. (2009), "Board of directors' size and performance in the banking sector," International Journal of Managerial Finance, Vo. 5, No. 2, pp. 201-221.

Bozzolan, S., Favotto, F., and Ricceri, F. (2003), "Italian annual intellectual capital disclosure, an empirical analysis," Journal of Intellectual Capital, Vol. 4, No. 4, pp. 543548.

Brennan, N. (2001), "Reporting intellectual capital in annual reports: Evidence from Ireland," Accounting, Auditing and Accountability Journal, Vol. 14, No. 4, pp. 423-436.

Brooking, A. (1997), “The management of intellectual capital," Long Range Planning, Vol. 30, No. 3, pp. 364-365.

Cerbioni, F., and Parbonetti, A. (2007), "Exploring the effects of corporate governance on intellectual capital disclosure: An analysis of European biotechnology companies," European Accounting Review, Vol. 16, No. 4, pp. 791-826.

Coff, R. W. (1997), "Human assets and management dilemmas: Coping with hazards on the road to resource-based theory," Academy of Management Review, Vol. 22, pp. 374402. 
Demirag, I., Sudarsanam, S., and Wright, M. (2000), "Corporate governance: Overview and research agenda," British Accounting Review, Vol. 32, pp. 341-54.

Donaldson, L., and Davis, J. H. (1991), "Stewardship theory or agency theory: CEO governance and shareholder returns," Australian Journal of Management, Vol. 16, pp. 49-64.

Donaldson, L., and Davis, J. H. (1994), "Boards and company performance - Research challenges the conventional wisdom," Corporate Governance: An International Review, Vol. 2, pp. 151-160.

Eccles, R. G., Herz, R. H., Keegan, E. M., and Phillips, D. M. H. (2001), The value reporting revolution: Moving beyond the earnings game. New York: Wiley.

Eisenhardt, K. M., and Bourgeois, L. J. (1988), "Politics of strategic decision making in high velocity environments: Towards a midrange theory," Academy of Management Journal, Vol. 32, pp. 543-577.

Edvinsson, L., and Sullivan, P. (1996), “Developing a model for managing intellectual capital," European Management Journal, Vol. 14, No. 4, pp. 356-64.

Fama, E. F. (1980), “Agency problems and the theory of the firm," Journal of Political Economy, Vol. 88, pp. 288-307. 
Fama, E. F., and Jensen, M. C. (1983), "Separation of ownership and control," Journal of Law and Economics, Vol. 26, pp. 301-325.

Garcia Lara, J. M., Garcia Osma, B., and Penalva, F. (2007), "Board of directors characteristics and conditional accounting conservatism: Spanish evidence," European Accounting Review, Vol. 16, No. 4, pp. 727-755.

Goyal, V. K., and Park, C. (2002), "Board leadership structure and CEO turnover," Journal of Corporate Finance, Vol. 8, pp. 49-66.

Gatamah, K. (1999), Launching corporate governance in Africa with an emphasis on Kenya: Private sector corporate governance trust. Washington DC: Center for International Private Enterprise.

Grant, R. M. (1997), "Strategy at the leading edge. The knowledge-based view of the firm: Implications for management practice," Long Range Planning, Vol. 30, pp. 450454.

Guthrie, J., and Parker, L. D. (1990), "Corporate social disclosure practice: A comparative international analysis," Advances in Public Interest Accounting, Vol. 3, pp. $159-175$. 
Hackston, D., and Milne, M. J. (1996), "Some determinants of social and environmental disclosures in New Zealand companies," Accounting, Auditing and Accountability Journal, Vol. 9, No. 1, pp. 77-108.

Haniffa, R. M., and Cooke, T. E. (2005), "The impact of culture and governance on corporate social responsibility," Journal of Accounting and Public Policy, Vol. 24, pp. $391-430$.

Hermalin, B., and Weisbach, M. (2003), "Boards of directors as an endogenously determined institution: A survey of the economic literature," FRBNY Economic Review April, pp. 7-26.

Hillman, A. J., Canella, A. A., and Paetzold, R. L. (2000), “The resource dependence role of corporate directors: Strategic adoption of board composition in response to environmental change," Journal of Management Studies, Vol. 37, No. 2, pp. 235-255.

Holland, L., and Boon Foo, Y. (2003), "Differences in environmental reporting practices in the UK and the US: The legal and regulatory context," The British Accounting Review, Vol. 35, No. 1, pp. 1-18.

Hunton, J. E., and Rose, J. M. (2008), “Can directors' self interests influence accounting choices?" Accounting, Organizations and Society, Vol. 33, pp. 783-800. 
Kaymak, T., and Bektas, E. (2008), "East meets west? Board characteristics in an emerging market: Evidence from Turkish banks," Corporate Governance, Vol. 16, No. 6, pp. $550-61$.

Keenan, J., and Aggestam, M. (2001), “Corporate governance and intellectual capital: Some conceptualisations," Corporate Governance, Vol. 9, No. 4, pp. 259-75.

Kosnik, R. D. (1990), “Effects of board demography and directors' incentives in corporate greenmail decisions," Academy of Management Journal, Vol. 11, pp. 93-110.

Laux, C., and Laux, V. (2009), "Board committees, CEO compensation, and earnings management," The Accounting Review, Vol. 84, No. 3, pp. 869-891.

Lev, B. (2001), Intangibles: Management, measurement and reporting. Washington, DC: Brookings Institution Press.

Lev, B. (2004), "Sharpening the intangible edge," Harvard Business Review, June, pp. pp. 109-116.

Lev, B., and Zarowin, P. (1999), “The boundaries of financial reporting and how to extend them," Journal of Accounting Research, Vol. 37, No. 2, pp. 353-385. 
Li, J., Pike, R., and Haniffa, R. (2008), “Intellectual capital disclosure and corporate governance structure in UK firms," Accounting and Business Research, Vol. 38, No. 2, pp. $137-159$.

Muth, M., and Donaldson, L. (1998), “Stewardship theory and board structure: A contingency approach," Corporate Governance: An International Review, Vol. 6, pp. 528.

Mwebesa, C. (2006), Corporate governance and financial markets. A speech by Chris Mwebesa, chief executive, Nairobi Stock Exchange at the Institute of Directors (Kenya) luncheon on 12 May 2006 at the Grand Regency Hotel.

Palepu, K. G., and Healy, P. (1993), “The effect of firms' financial disclosure strategies on stock prices," Accounting Horizons, Vol. 7, pp. 1-11.

Parum, E. (2005), “Does disclosure on corporate governance lead to openness and transparency in how companies are managed?" Corporate Governance, Vol. 13, No. 5, pp. 702-709.

Pfeffer, J. (1972), “Size and composition of corporate boards of directors: The organization and its environment," Administrative Science Quarterly, Vol. 17, pp. 21828. 
Pfeffer, J. (1973), "Size, composition and function of hospital boards of directors: A study of organization-environment linkage," Administrative Science Quarterly, Vol. 18, pp. 349-64.

Pfeffer, J., and Salancik, G. R. (1978), The external control of organizations: A resource dependence perspective. New York: Harper and Row.

Quinn, J. B., Anderson, P., and Finkelstein, S. (1996), "Making the most of the best," Harvard Business Review Vol. 74, No. 2, pp. 71-80.

Roos, G., and Roos, J. (1997), "Measuring your company's intellectual performance," Long Range Planning, Vol. 30, pp. 413-426.

Schweiger, D., Sandberg, W., and Ragan, J. (1986), “Group approaches for improving strategic decision making: A comparative analysis of dialectical inquiry, devil's advocacy, and consensus," Academy of Management Journal, Vol. 29, pp. 51-71.

Scott, W. A. (1955), "Reliability of content analysis: The case of nominal scale coding," The Public Opinion Quarterly, Vol. 19, pp. 321-325.

Shleifer, A., and Vishny, R. W. (1997), "A survey of corporate governance," Journal of Finance, Vol. 52, No. 2, pp. 737-783. 
Simister, M., Roest, P., and Sheldon, J. (1998), “CFO of the future,” Institute of Chartered Accountants in Australia, Sydney.

Spira, L. (Ed.). (2002), Audit committees: Performing corporate governance. Boston: Kluwer Academic.

Tuley, S. (2003), “Audit committees - Performing corporate governance," British Accounting Review, Vol. 35, pp. 194-196.

Van der Meer-Kooistra, J., and Zijlstra, S. (2001), "Reporting on intellectual capital,” Accounting, Auditing and Accountability Journal, Vol. 14, No. 4, pp. 456-476.

Vandemaele, S. N., Vergauwen, P. G. M. C., and Smits, A. J. (2005), "Intellectual capital disclosure in the Netherlands, Sweden and the UK," Journal of Intellectual Capital, Vol. 6, pp. 417-426.

Wallace, R. S. O. (1988), “Corporate financial reporting in Nigeria," Accounting and Business Research, Vol.18, pp. 352-362.

Williams, S. M. (2001), "Is intellectual capital performance and disclosure practices related?," Journal of Intellectual Capital, Vol. 2, pp. 192-203. 
World Bank. (2001). Report on the observance of standards and codes (ROSC) Kenya. Washington, DC: World Bank. 